7. Reprod. Fert. (1969) 19, 519-526

\title{
THE EFFECTS OF STARVATION OR OF TREATMENT WITH CYTOTOXIC AGENTS ON PREGNANCY IN MICE
}

\author{
D. O. E. GEBHARDT \\ National Institute of Public Health, Utrecht, Holland \\ (Received 17th Fuly 1968, revised 7th October 1968)
}

\begin{abstract}
Summary. In mice at different stages of pregnancy, a comparison was made between the embryotoxic effect of starvation and of treatment with one of the following antimitotic substances: aminopterin, 6aminonicotinamide or actinomycin $\mathrm{D}$. The presence of embryonic resorptions was established by immersing the uterus in a $10 \%$ solution of ammonium sulphide.

When pregnant mice were starved for $24 \mathrm{hr}$, the 6 th day was the most effective time for inducing resorptions. The most sensitive period for inducing resorptions with aminopterin was the 8th and 9th days of pregnancy. The great decline in sensitivity of the embryo on the 10th day was also observed after injecting 6-aminonicotinamide or actinomycin D.

Growth retardation of embryos or young mice occurred only if the maltreatment was initiated after implantation. The antimitotic substance 6-aminonicotinamide caused a more permanent stunting than $48 \mathrm{hr}$ of starvation.
\end{abstract}

\section{INTRODUCTION}

In pregnant rodents, fasting (McClure, 1967) or the administration of an antimitotic substance (Thiersch \& Phillips, 1950; Didcock, Jackson \& Robson, 1956) may cause embryonic death. Little systematic work has been done so far on determining the period of gestation during which the embryo is sensitive to such treatment. The aim of the present study was to supply more information on this subject with reference to the following three questions: (i) Can different types of embryotoxic agents induce resorptions during different periods of pregnancy? (ii) Do embryos surviving the embryotoxic action show permanent or transient growth retardation? (iii) If so, is the induction of this deficiency dependent on the stage of pregnancy when the agent is applied?

\section{METHODS}

The experiments were performed with 9- to 10-week-old, randomly bred, Swiss mice. They were primigravidae with an average weight of $28 \mathrm{~g}$ at the 
time of mating. The females were examined daily for vaginal plugs at 08.30 hours. When a plug was found, the day was called the 1st day of embryonic development. The male was then removed and the impregnated females were put together in plastic cages in groups of three. All except the fasting mice had free access to food (Muracon I pellets from Trouw, Amsterdam).

On the 18th day of pregnancy, counts were made of resorption sites in the uterus following a single intraperitoneal injection of an antimitotic agent or a 24- or 48-hr period of starvation on various days of pregnancy, as described in the Results. The antimitotic substances, in aqueous medium, included aminopterin (Koch-Light, Colnbrook, England) dissolved in $1 \%$ sodium bicarbonate and 6-aminonicotinamide (Sigma, St. Louis, Mo.) dissolved in 1\% ammonium chloride. Actinomycin D was obtained from Merck, Sharp and Dohme, Rahway, N. J. About twenty mice were used for each dose. Drugs were freshly prepared every 3rd day. Resorption sites were easily recognized if the embryo died late in pregnancy, but if death occurred during the early post-implantation period, the resorptions were only visible if the uterus was immersed in a $10 \%$ solution of ammonium sulphide for 10 min (Kopf, Lorenz \& Salewski, 1964). A post-implantation treatment was considered to be embryotoxic when more than three embryos were resorbed per uterus. This was a minimum requirement because a study of 200 pregnant control uteri had shown that up to three resorptions could occur spontaneously.

Pre-implantation death, an all-or-none phenomenon, was not detected by immersing the uterus in ammonium sulphide, but could be assessed by comparing the pregnancy frequency of control and treated mice.

Growth retardation was established by weighing on a Mettler P 1200 balance with a precision of $0.05 \mathrm{~g}$. The weights of about seventy foetuses or young mice from treated mothers were compared with the weights of about seventy control offspring. The weights of embryos from the same mother are dependent variables so that, to improve the sampling technique, four foetuses were taken from each of eighteen mice of one group and were always derived from the same site in the uterus, namely the first two foetuses on the left and on the right side of the cervix. The sum of the weights of the four foetuses was used for the statistical evaluation of the results. The significance of weight differences was determined with the distribution free test of Kruskal and Wallis (de Jonge, 1963). Fluctuations in weight, due to litter size, were avoided by allowing each mother to nurse eight young.

\section{RESULTS}

The determination of an embryotoxic effect after treatment during early pregnancy

Embryos resorbed after implantation, i.e. on the 6th day or later, were stained by ammonium sulphide. An embryotoxic effect was more difficult to establish if the agent was administered on the 5 th day or earlier. In that case, a comparison had to be made between the pregnancy frequency of treated and control groups (Table 1 and Table 2). When the former was significantly lower than the latter, it was concluded that the agent had either killed the embryo or had prevented implantation. 
The embryotoxic effect of aminopterin, 6-aminonicotinamide or actinomycin $D$

The effect of aminopterin on the pregnant mouse was studied both by injecting it on different days of development and by using different doses (Text-fig. 1). Aminopterin, in a dose ranging from 0.2 to $3 \mathrm{mg} / \mathrm{kg}$, was highly embryotoxic

\section{TABLE 1}

THE INFLUENCE OF AMINOPTERIN ON THE PREGNANCY FREQUENCY* OF MICE

\begin{tabular}{c|c|c|c}
\hline $\begin{array}{c}\text { Day of development } \\
\text { when injected }\end{array}$ & $\begin{array}{c}\text { Dose } \\
(\mathrm{mg} / \mathrm{kg})\end{array}$ & $\begin{array}{c}\text { No. of } \\
\text { mice }\end{array}$ & $\begin{array}{c}\text { Pregnancy frequenc* } \\
(\%)\end{array}$ \\
\hline Control & - & 20 & 90 \\
1 & 2 & 21 & 91 \\
2 & 2 & 20 & 90 \\
3 & 2 & 21 & 95 \\
4 & 2 & 22 & 91 \\
1 & 3 & 21 & $48 \dagger$ \\
2 & 3 & 22 & $59 \dagger$ \\
3 & 3 & 21 & 72 \\
4 & 3 & 19 & 84 \\
5 & 3 & 20 & 90 \\
\hline
\end{tabular}

* Pregnancy frequency is defined here as the percentage of mice in which embryos or resorption sites were present in the uterus on the 18th day.

† The $95 \%$ confidence limits of the control pregnancy frequency of $90 \%$ and a sample size of twenty are $69 \%$ to $99 \%$ (Pearson \& Hartley, 1962). Therefore the frequencies marked with $\dagger$ are significantly reduced.

TABLE 2

THE INFLUENGE OF FASTING ON THE PREGNANCY FREQUENCX* OF MICE

\begin{tabular}{c|c|c}
\hline $\begin{array}{c}\text { Day }(s) \text { of development } \\
\text { when fasting }\end{array}$ & No. of mice & Pregnancy frequency* \\
\hline Control & 20 & \\
1 & 20 & 90 \\
2 & 20 & 90 \\
3 & 20 & 100 \\
4 & 21 & 90 \\
$1+2$ & 22 & 91 \\
$2+3$ & 21 & 87 \\
$3+4$ & 41 & $62 \dagger$ \\
$4+5$ & 21 & $39 \dagger$ \\
\hline
\end{tabular}

* For definition see footnote to Table 1 .

$\uparrow$ Significantly reduced when compared with control value (Pearson \& Hartley, 1962). $P<0.05$.

on the 9th but not on the 10th day. A similar change in response was observed when either 6-aminonicotinamide or actinomycin D was injected on these days (Text-fig. 2). Only when the mothers were injected with very high doses ( $4 \mathrm{mg} / \mathrm{kg}$ aminopterin $=\mathrm{LD}_{10}$ ), did the observed difference in embryonic mortality disappear (see Text-fig. 1). 


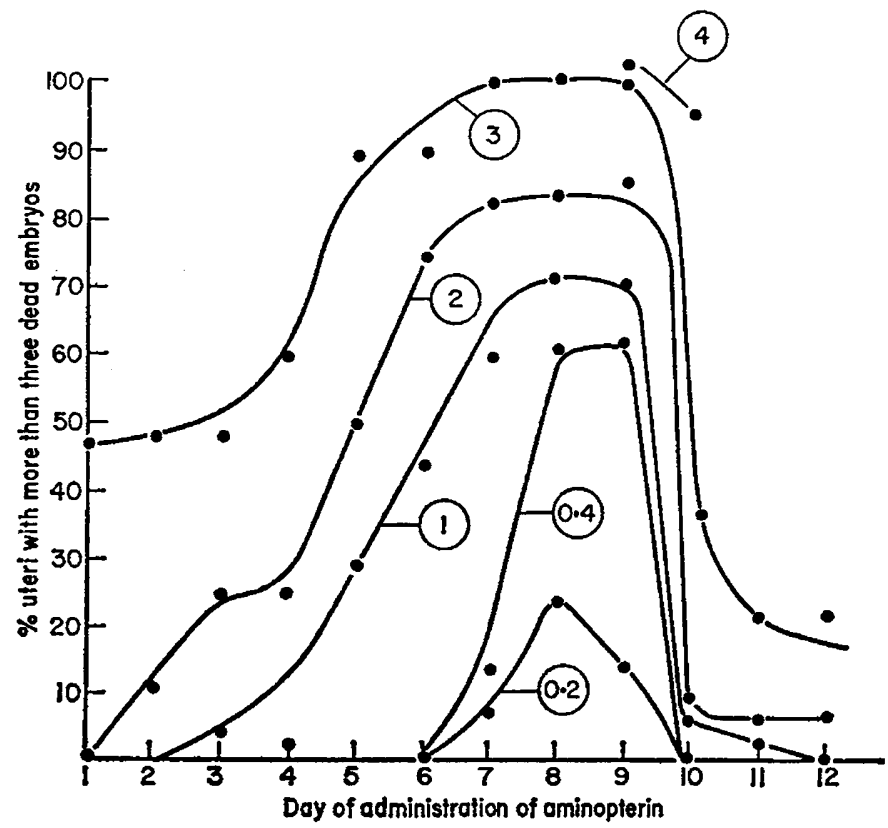

Text-rig. 1. The effect on embryonic mortality of different doses of aminopterin (encircled number $=$ dose in $\mathrm{mg} / \mathbf{k g}$ ) injected on different days of pregnancy. The percentage of uteri containing more than three dead embryos on the 18th day is given. For each point about twenty mice were used.
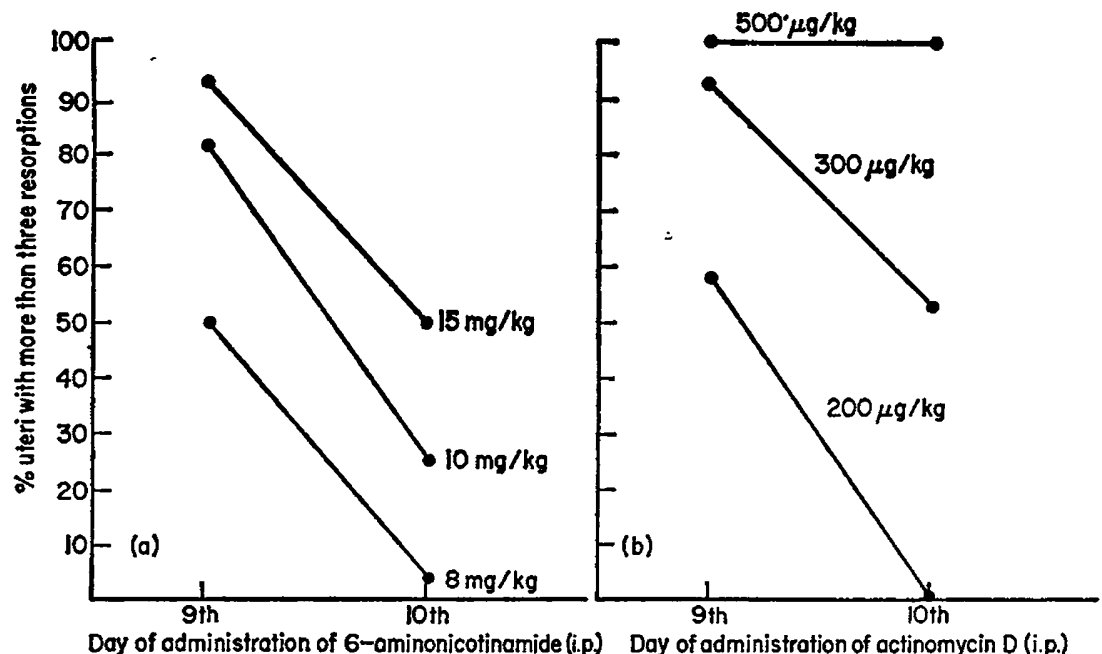

TEXT-FIG. 2. The effect on embryonic mortality of different doses of (a) 6-aminonicotinamide or (b) actinomycin $D$, injected on the 9 th or 10 th day of development. The percentage of uteri containing more than three resorbed embryos on the 18th day is given. For each point about twenty mice were used. 
The pre-implantation embryo was resistant to a dose of aminopterin $(0.4$ $\mathrm{mg} / \mathrm{kg}$ ) which was embryotoxic on the 8 th or 9 th day.

\section{The embryotoxic effect of fasting}

Starvation either caused the death of all embryos in the uterus or permitted all embryos to survive. In Text-fig. 3(a), the influence on embryonic mortality
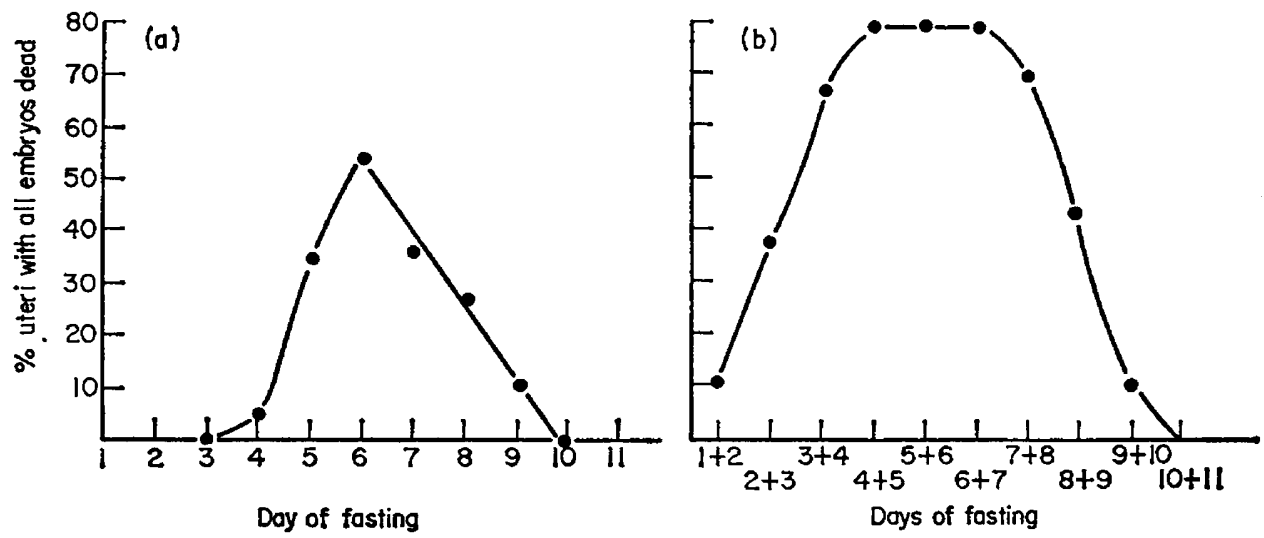

TEXT-FIc. 3. The effect on embryonic mortality of (a) $24 \mathrm{hr}$ or (b) $48 \mathrm{hr}$ of fasting on different days of pregnancy. The percentage of uteri in which all embryos were dead on the 18th day is given. For each point about twenty mice were used.

TABLE 3

AVERAGE WEIGHTS (IN G) OF 18-DAY-OLD EMBRYOS FROM TREATED OR CONTROL DAMS (SEVENTY FOETUSES/GROUP)

\begin{tabular}{l|cccccccc}
\hline & \multicolumn{7}{|c}{ Day(s) of pregnancy when treated } \\
\cline { 2 - 8 } & 4 theatment & 8 th & 12 th & 11 th-12th & 14 th & 14 th-15th & 16 th \\
\hline Fasting & 1.06 & 1.05 & 1.05 & 0.97 & 0.98 & $0.93^{*}$ & $0.91^{*}$ \\
Control & 1.01 & 1.08 & 1.08 & 1.01 & 1.04 & 1.01 & 1.01 \\
Aminopterin, $2 \mathrm{mg} / \mathrm{kg}$ & 1.00 & - & $0.92 \dagger$ & - & $0.78 \dagger$ & - & $0.89^{*}$ \\
Control & 1.00 & & 1.02 & & 0.99 & & 0.99 \\
6-Aminonicotinamide, $10 \mathrm{mg} / \mathrm{kg}$ & 0.98 & $0.98 \dagger$ & $0.83 \dagger$ & - & $0.81^{*}$ & - & $0.79 \dagger$ \\
Control & 1.02 & 1.08 & 1.09 & & 0.99 & & 0.99 \\
\hline
\end{tabular}

* Significant difference, $P<0.005$.

† Significant difference, $P<0.0005$.

$-=$ no weighing experiments performed.

of starving pregnant mice for $24 \mathrm{hr}$ is shown. When food was withheld for $48 \mathrm{hr}$, the sensitive period for the induction of embryonic death was somewhat extended (Text-fig. 3b). The pre-implantation embryo appeared to be insensitive to $24 \mathrm{hr}$ of fasting (Table 2, Text-fig. 3a). By increasing the period to $48 \mathrm{hr}$, however, there was a great reduction in the pregnancy frequency (Table 2, Text-fig. 3b). 
Relative weight changes in embryos and offspring

The weight change in offspring of mothers, fasting or treated with an antimitotic substance during pregnancy, was determined either on the 18th day of embryonic development (Table 3) or on the 2nd and 21st days after birth (Table 4).

From Table 3, it is seen that during the pre-implantation period neither fasting nor injection of an antimitotic substance induced growth retardation in the foetuses. In the post-implantation period, fasting caused a reduction in embryonic weight on the 18th day only if the period between treatment and weighing was relatively short. Thus, the 12-day-old embryo was either insensitive to starvation or had recovered from it by the 18th day. On the other hand, injection of an antimitotic agent shortly after implantation significantly retarded embryonic growth.

TABLE 4

\begin{tabular}{|c|c|c|}
\hline $\begin{array}{c}\text { AVERAGE WEIGHT OF } \\
\text { FROM TREATED OR } \\
\text { YOUNC }\end{array}$ & $\begin{array}{l}\text { AND 21-1 } \\
\text { TROL D } \\
\text { ROUP) }\end{array}$ & $\begin{array}{l}\text {-OLD MICE } \\
\text { (SEVENTTY }\end{array}$ \\
\hline Treatment during pregnancy & $\begin{array}{l}\text { Weight on } \\
\text { 2nd day }\end{array}$ & $\begin{array}{l}\text { Weight on } \\
21 \text { st day }\end{array}$ \\
\hline $\begin{array}{l}\text { Control } \\
\text { Fasting } 14 \text { th }+15 \text { th day } \\
6 \text {-Aminonicotinamide, } \\
\quad 10 \mathrm{mg} / \mathrm{kg} \text { on } 14 \text { th day }\end{array}$ & $\begin{array}{l}2 \cdot 15 \\
1 \cdot 92^{*} \\
1 \cdot 98^{*}\end{array}$ & $\begin{array}{l}15 \cdot 06 \\
14 \cdot 88\end{array}$ \\
\hline
\end{tabular}

* Weight significantly lower than control; $P<0.0005$.

Both fasting and treatment with 6 -aminonicotinamide during the later part of pregnancy yielded lighter offspring on the 2nd day post partum (Table 4), but by the 21 st day after birth the young mice from fasting mothers had recovered. Those from mothers treated with 6 -aminonicotinamide were still significantly lighter than the controls.

\section{DISCUSSION}

The ammonium sulphide method of locating embryonic resorptions is based on the discovery by Wislocki, Deane \& Dempsey (1946) that the placenta of the rat contains iron. Nylander (1953) confirmed these authors' result and established that the iron was present in the villous portion of the visceral yolk sac in the form of ferritin.

The sensitive period for inducing resorptions is somewhat dose dependent, e.g. $0.4 \mathrm{mg} / \mathrm{kg}$ aminopterin is only embryotoxic on the 8th or 9 th day, whereas $1 \mathrm{mg} / \mathrm{kg}$ is toxic from the 5 th to the 9 th day. The pre-implantation embryo does not appear to respond to doses lower than $1 \mathrm{mg} / \mathrm{kg}$. It remains to be seen whether this is due to lack of penetration into the embryo before a placenta is formed. Aminopterin does reach the embryo after implantation. Preliminary experiments (Gebhardt, 1966) have shown that the difference in response on the 9 th and 10th days cannot be attributed to a difference in drug penetration. It is 
possible that the change in sensitivity is related to a change in nutritional requirement of the embryo at the 10th day (Beck \& Lloyd, 1965).

The mechanism by which aminopterin exerts its effect on the rat embryo has been studied by Baranov (1966). He found that it caused a selective damage to the ectoplacental cone cells. In an earlier paper, Baranov (1965) reported that pregnant rats receiving a low dose of aminopterin $(0.075 \mathrm{mg} / \mathrm{kg})$ on the $7 \mathrm{th}$ or 10th day resorbed most of their embryos, but on the 8th day the embryos were insensitive to this treatment. Such intermittent periods of sensitivity were not encountered in the present investigation.

The sharp decrease in embryonic resorptions after injection of aminopterin on the 10th day was also observed when 6-aminonicotinamide or actinomycin $\mathrm{D}$ was used. On the other hand, the period in which fasting caused resorptions did not coincide with the period found for the antimitotic agents. The different mechanisms of inducing embryonic death may be responsible for this. Starvation causes a reduction in the level of pituitary and placental gonadotrophins, which leads to failure in reproduction (McClure, 1961; Kinzey \& Srebnik, 1963).

It is of interest that starvation, when effective, always resulted in the death of all the embryos, a phenomenon also observed in the rat by Berg (1965). When antimitotic substances were injected the uterus contained a few survivors. Death of all embryos occurred only when injection took place before implantation (Table 1) or when very high doses of these agents were used after implantation (for instance $4 \mathrm{mg} / \mathrm{kg}$ aminopterin $=\mathrm{LD}_{10}$ for the mother).

In Table 2, it is shown that $48 \mathrm{hr}$ of starvation instituted on the 3rd and 4th days resulted in complete inhibition of pregnancy in about $60 \%$ of the mice. According to McClure (1967), the major cause of infertility after such treatment is death of the ova before implantation. Whether this also holds for mice treated with $3 \mathrm{mg} / \mathrm{kg}$ aminopterin early in pregnancy (Table 1) is still unknown.

The weight decrease of embryos and young mice from dams treated with cytostatic agents (Tables 3 and 4 ) is more permanent than the decrease in weight of the young from starved mothers. Chow \& Lee (1964), however, found a permanent stunting in young rats when their mothers had been kept on a restricted diet during the whole period of pregnancy. It may be deduced that $48 \mathrm{hr}$ of fasting on the 14th and 15th days is less detrimental to the offspring than a continuous dietary restriction during gestation. In man, the effect of starvation during pregnancy is not as severe as in rodents. Payne \& Wheeler (1967) believe that this is associated with the less exacting demands made on the mother by the slower-growing primate foetus.

Neither starvation nor treatment with an antimitotic agent during the preimplantation period could induce growth retardation (Table 3). Russell (1954) did not find stunting in new-born mice from mothers irradiated before implantation. Only when irradiation took place during later stages of pregnancy, was the mean birth-weight reduced. These results have recently been confirmed by Brent \& Bolden (1967) who compared the growth retardation in embryos of rats irradiated with $150 \mathrm{R}$ on the 1st and 6 th day of gestation.

An explanation for the insensitivity of the early embryo towards the growth- 
retarding effect of these agents remains speculative at present. The pre-implantation embryo may have a better repair mechanism than older embryos and the young embryo may be less dependent on an external food supply. Since many toxic agents probably act by reducing the amount of nutrition available to the embryo, their influence would not be felt until after implantation.

\section{ACKNOWLEDGMENTS}

I would like to thank Professor J. van Noordwijk for critically reading the manuscript. I am very grateful to my colleague Dr B. Kruyt for the regular supply of pregnant mice. Miss G. B. van Drie and Miss G. Klepper gave me excellent technical assistance. Merck, Sharp and Dohme presented me with the actinomycin D.

\section{REFERENCES}

Baranov, V. S. (1965) Injurious effect of aminopterin at different stages in the embryonic development of rats. Dokl. Akad. Nauk SSSR, 163, 1032.

Baranov, V. S. (1966) Mechanism of aminopterin pathogenic effect upon embryogenesis in the albino rat. Arkh. Anat. Gistol. Embriol. 51, 17.

BECK, F. \& LLoYd, J. B. (1965) Embryological principles of teratogenesis. In: Symposium on Embryopathic Activity of Drugs. Ed. J. M. Robson. Churchill, London.

BERG, B. N. (1965) Dietary restriction and reproduction in the rat. F. Nutr. 87, 344.

BRENT, R. L. \& Bolden, B. T. (1967) The indirect effect of irradiation on embryonic development. Radiat. Res. 30, 759.

Chow, B. F. \& LEE, C. (1964) Effects of dietary restriction of pregnant rats on bodyweight gain of the offspring. F. Nutr. 82, 10.

Didcock, K., Jackson, D. \& Robson, J. M. (1956) The action of some nucleotoxic substances on pregnancy. Br. F. Pharmac. 11, 437.

GebhardT, D. O. E. (1966) Diskussion in Biochemie und Pathochemie des Keimstoffwechsels. Bull. Swiss Acad. med. Sci. 22, 97.

DE Jonge, H. (1963) Inleiding tot de medische statistiek, 2nd edn, p. 301. Nederlands Instituut voor Praeventiere Geneeskunde, Leiden.

KinzeY, W. G. \& SREBNIK, H. H. (1963) Maintenance of pregnancy in protein-deficient rats with short term injections of ovarian hormones. Proc. Soc. exp. Biol. Med. 114, 158.

Kopf, R., Lorenz, D. \& Salewskr, E. (1964) Der Einfluss von Thalidomid auf die Fertilität von Ratten im Generationsversuch über zwei Generationen. Naunyn-Schmiedeberg's Arch. exp. Path. Pharmak. 247, 121.

McClure, T. J. (1961) Pathogenesis of early embryonic mortality caused by fasting pregnant rats and mice for short periods. F. Reprod. Fert. 2, 381.

MCCluRE, T. J. (1967) Infertility in mice caused by fasting at about the time of mating. F. Reprod. Fert. 13, 387.

NyLANDer, G. (1953) On the placental transfer of iron. Acta physiol. scand. 29, Suppl. 107, 1.

PAYNe, P. R. \& WhEELER, E. F. (1967) Comparative nutrition in pregnancy. Nature, Lond. 215, 1134.

Pearson, E. S. \& Hartley, H. O. (1962) Biometrika tables for statisticians, Vol. 1, Table 41. Cambridge University Press.

Russels, L. B. (1954) The effects of radiation on mammalian prenatal development. In: Radiation Biology I, part 2, p. 861. Ed. A. Hollaender. McGraw-Hill, New York.

Thiersch, J. B. \& Phitips, E. S. (1950) Effects of 4-aminopteroyl glutamic acid (aminopterin) on early pregnancy. Proc. Soc. exp. Biol. Med. 74, 204.

Wislocki, G. B., Deane, H. W. \& Dempsey, E. W. (1946) The histochemistry of the rodent's placenta. Am. J. Anat. 78, 281. 